\title{
Pemanfaatan Pasar Tradisional sebagai Sumber Belajar pada Mata Pelajaran Ekonomi Kelas X
}

\author{
Dimas Caesar Ricardika ${ }^{1}$, Aan Anisah ${ }^{2}$ \\ ${ }^{1,2}$ Pendidikan Ekonomi Universitas Swadaya Gunung Jati \\ ${ }^{1}$ Email: dimascr235@gmail.com; ${ }^{2}$ Email: aananisah.ugj@gmail.com
}

(Received: 21 September 2020; Accepted: 15 Desember 2020; Published: 10 Januari 2021)

\begin{abstract}
Abstrack. This study aims to determine how the use of traditional markets as a learning resources in Economics in Senior High School and how to design Student Worksheet. This study uses a qualitative research method with four steps of data analysis, namely data collection, data reduction, data display and conclusion and verification of data. The subject of this research is aimed at managers, trades and buyers at the Cilimus Traditional Market as research objects. The results showed that economic activities in the Cilimus Traditional Market which can be used as a learning resource in Economics in the chapter material on Equilibrium and Market Structure are: 1) Merchandise distribution activities, 2) merchandise storage, 3) presentation of merchandise, and 4) sale and purchase transactions. This traditional market-based student worksheet is feasible to be developed after validating with the result of 3,86 which shows relevance/good.
\end{abstract}

Keywords: Traditional Market; Learning Resources; Student Worksheet

\begin{abstract}
Abstrak. Penelitian ini bertujuan untuk mengetahui bagaimana pemanfaatan pasar tradisional sebagai sumber belajar pada mata pelajaran Ekonomi di SMA dan bagaimana cara desain bahan ajar LKS. Penelitian ini menggunakan metode penelitian kualitatif dengan empat langkah analisa data yaitu pengumpulan data, reduksi data, penyajian data serta penarikan kesimpulan dan verifikasi data. Subjek penelitian ini ditujukan kepada pengelola, pedagang dan pembeli di Pasar Tradisional Cilimus sebagai objek penelitian. Hasil penelitian menunjukan kegiatan ekonomi di Pasar Tradisional Cilimus yang dapat dimanfaatkan sebagai sumber belajar pada mata pelajaran Ekonomi pada materi bab Keseimbangan dan Struktur Pasar yaitu: 1) Kegiatan distribusi barang dagangan, 2) Penyimpanan barang dagangan, 3) Penyajian barang dagangan, dan 4) Transaksi jual beli. Bahan ajar LKS berbasis pasar tradisional ini layak untuk dikembangkan setelah melakukan validasi dengan hasil 3,86 yang menunjukan relevan/baik.
\end{abstract}

Kata Kunci: Pasar Tradisional; Sumber Belajar; Lembar Kerja Siswa

\section{PENDAHULUAN}

Pendidikan adalah hal yang terpenting dalam membentuk kepribadian berpikir melalui pengetahuan, keterampilan, pengalaman dan wawasan akan memperoleh ilmu pengetahuan untuk kebutuhan hidupnya dengan tujuan menjadi insan manusia yang berkualitas. Pendidikan yang berkualitas menjadi jalan lahirnya sumber daya manusia yang berkualitas (Rahmatullah, Inanna, Rakib, et al., 2020). Pendidikan akan terus dibutuhkan sejalan dengan kebutuhan manusia dalam menjalankan aktivitas dalam segala kehidupan, dari pendidikanlah ilmu akan diperoleh, dengan pendidikan juga derajat manusia akan berkembang ke arah yang lebih baik. Hal ini dapat dimaknai bawah proses Pendidikan merupakan salah satu investasi untuk kemajuan bangsa (Yulianti, 2019).

Pembelajaran merupakan proses kegiatan belajar mengajar yang juga berperan dalam menentukan keberhasilan belajar siswa. Dari proses pembelajaran itu akan terjadi sebuah kegiatan timbal balik antara guru dengan siswa dalam mencapai tujuan pembelajaran. Dalam proses pembelajaran, guru dan siswa merupakan dua komponen yang tidak bisa dipisahkan. Antara dua komponen tersebut harus terjalin interaksi yang saling menunjang agar hasil 
belajar siswa dapat tercapai secara optimal. Peran guru yang inovatif dibutuhkan sebagai fasilitator agar dapat membantu siswa mengembangkan potensinya untuk mendapatkan pengetahuan dan pengalaman baru selama proses belajar mengajar (Ramli, Rahmatullah, Inanna, \& Dangnga, 2018)

Siswa membutuhkan belajar dengan lingkungannya sebagai tempat bagaimana seseorang itu bertindak untuk mempertahankan kehidupannya. Pendidikan dapat membawa perubahan pada diri siswa dalam lingkungan dan masyarakat, sehingga menjadi solusi bagi berbagai problema kehidupan yang akan dihadapi siswa dimasa yang akan datang (Rahmatullah, Inanna, \& Ampa, 2020). Dengan demikian, belajar tidak selalu harus di sekolah, lingkungan sekitar pun bisa dijadikan tempat belajar. Termasuk juga pasar bisa dijadikan sumber belajar yang berkaitan dengan pembelajaran ekonomi di SMA.

Lukman (2007:13) mengatakan bahwa pasar adalah pertemuan antara para pembeli dan penjual (konsumen dan produsen) untuk suatu keinginan menentukan kondisi bagi pertukaran sumber daya (barang dan jasa) atau dengan kata lain merupakan pertemuan transaksi antara permintaan dan penawaran yang tidak dibatasi oleh ruang, waktu dan tempat.

Aktivitas yang terjadi di Pasar Tradisional dapat digunakan sebagai sumber belajar ekonomi mulai dari bentuk jual beli, seperti tukar menukar barang dengan uang, aktivitas kegiatan masyarakat di pasar, barang-barang apa saja yang diperjualbelikan, keadaan pasar setiap harinya serta keamanan dan ketertiban pasar.

Pasar dapat dijadikan sebagai sumber belajar alternatif selain buku paket sehingga pembelajaran akan mejadi kontekstual. Menurut Abdul Majid (2011:170) sumber belajar adalah informasi yang disajikan dan disimpan dalam bentuk media (cetakan, video, perangkat lunak atau kombinasi dari berbagai format) yang dapat membantu siswa dalam belajar sebagai perwujudan kurikulum.

Dalam mencapai tujuan pembelajaran yang diharapkan, siswa tidak hanya sebatas mencermati dan mendengarkan apa yang diterangkan oleh guru. Siswa juga membutuhkan sumber belajar lain untuk menggali ilmu agar pemahamannya lebih luas sehingga kemampuannya dapat dioptimalkan.

Sumber belajar menurut AECT 2004 menyatakan bahwa teknologi pendidikan adalah studi dan praktek etis dalam upaya memfasilitasi pembelajaran dan meningkatkan kinerja dengan cara menciptakan, menggunakan atau memanfaatkan, dan mengelola proses dan sumber-sumber teknologi yang tepat. Tujuan utamanya untuk memfasilitasi pembelajaran agar efektif, efisien, menarik dan meningkatkan kinerja.

Buku paket yang digunakan di SMA Negeri 1 Cilimus hanya menyajikan materi dan soal-soal pilihan ganda serta essay yang belum berbasis lingkungan. Oleh karena itu siswa diharapkan memiliki buku pegangan yang dapat mengeksplorasi pengetahuan siswa yang didukung oleh sumber belajar dari lingkungan yang ada disekitarnya.

Lembar Kerja Siswa (LKS) menurut Prastowo (2011:208) yaitu bahan ajar yang terdiri dari beberapa materi, sehingga siswa diharapkan dapat mempelajari materi tersebut secara mandiri. Kisiel (Mustofa, dkk, 2013:116) mengatakan bahwa LKS dapat berperan sebagai scaffolding (rangka) yang digunakan untuk membantu kegiatan pembelajaran di lingkungan luar kelas (lingkungan nonformal) dengan cara menentukan penugasan pada objek yang spesifik sehingga siswa dapat fokus pada materi yang sedang dipelajari dan tujuan belajar pun dapat tercapai.

Berdasarkan uraian latar belakang diatas, maka fokus dari artikel ini terkait dengan bagaimana pemanfaatan pasar sebagai sumber belajar pada mata pelajaran ekonomi dan bagaimana desain LKS berbasis lingkungan untuk mata pelajaran ekonomi.

Menurut Pasal 1 ayat 2 Perpres No. 112 tahun 2007; Polanyi (Brata, 2016:4); Fitria Sari (Rita, dkk, 2005:36) pasar tradisional adalah tempat bertemunya penjual dan pembeli dimana pasar tradisional dibangun dan dikelola oleh pemerintah, pemerintah daerah, swasta dan badan usaha milik negara serta badan usaha milik daerah.

Dalam pasar terdapat aliran barang dan uang dimana hal ini membentuk terjadinya pasar, baik pasar barang konsumsi maupun pasar barang produksi, menurut Suparmoko (Hidayat 2014:12) Emy Lestary (2017:11) peranan pasar yaitu dapat berfungsi sebagai sarana distribusi, sebagai alat pembentuk nilai atau harga barang serta sebagai tempat untuk mendistribusikan produk.

Dalam mencapai tujuan pembelajaran yang diharapkan, siswa tidak hanya sebatas mencermati dan mendengarkan apa yang diterangkan oleh guru. Siswa juga membutuhkan 
sumber belajar lain untuk menggali ilmu agar pemahamannya lebih luas sehingga kemampuannya dapat dioptimalkan.

Sumber belajar menurut AECT 2004 Hamdani (2011:118); Warsita (Merida, dkk, 2016:1218) sumber belajar yang dimaksud adalah sumber belajar yang berupa media, media bisa berbentuk cetak, video, narasumber, lingkungan sekitar dan sebagainya yang pada dasarnya sumber belajar seperti ini untuk pengembangan proses belajar mengajar supaya lebih efektif sehingga siswa akan lebih dekat dengan lingkungannya dan pengetahuan akan sebuah ilmu lebih mudah dipahami dan dapat diserap yang nantinya menjadi hal yang baik untuk pembelajaran kedepannya.

Suatu kegiatan belajar mengajar akan lebih efektif dan efisien dalam usaha pencapaian instruksional, jika melibatkan komponen sumber belajar secara terencana. Sebab, sumber belajar sebagai komponen penting dan sangat besar manfaatnya. Menurut Reigeluth (Ramli, 2012:222); Alvin Hidayat (2014:15) manfaat sumber belajar diantaranya dapat member informasi yang akurat dan terbaru, dapat membantu memecahkan masalah pendidikan (instruksional) baik dalam lingkup mikro maupun makro, dapat memberi motivasi yang positif, apabila di atur dan direncanakan pemanfaatannya secara tepat dan dapat merangsang untuk berfikir, bersikap dan berkembang lebih lanjut.

Sumber belajar memiliki peran yang sangat penting dengan hubungannya dalam menyusun bahan ajar. Bahan ajar disusun menggunakan bahan-bahan dari berbagai macam sumber. Menurut Andi Prastowo (2012:17) ; (Majid 2008:174) ; Depdiknas (2006:4) bahan ajar adalah seperangkat mater pelajaran yang dapat membantu tercapainya tujuan kurikulum yang disusun secara sistematis dan utuh sehingga tercipta linkungan belajar yang menyenangkan, memudahkan siswa belajar dan guru dalam mengajar.

Bahan ajar memiliki berbagai jenis dan bentuk. Beberapa menjadi criteria dalam membuat klasifikasi tersebut. Bentuk bahan ajar menurut Andi Prastowo (2014:40-43); Rowntree (Belawati, dkk, 2003:42) bahwasanya bahan ajar beragam bentuknya. Ada bahan ajar cetak, bahan ajar audio yang dapat didengar serta bahan audiovisual yaitu bahan ajar yang dapat dilihat dan didengar.

LKS pada umumnya dibeli dan bukan dibuat sendiri oleh guru. Padahal, LKS sebenarnya bisa dibuat sendiri oleh guru sehingga LKS dapat lebih menarik serta lebih kontekstual dengan situasi dan kondisi sekolah ataupun lingkungan sosial budaya peserta didik.

Menurut Belawati, dkk, (Prastowo, 2015:2014) ; Pedoman Umum Pengembangan Bahan Ajar (Diknas, 2004) ; Abdul Majid (2011:176) LKS yaitu lembaran yang berisi tugas-tugas guru kepada siswa yang disesuaikan dengan kompetensi dasar dan dengan tujuan pembelajaran yang ingin dicapai sehingga dapat mempermudah siswa dalam melaksanakan kegiatan pembelajaran.

Berbicara mengenai pentingnya LKS bagi kegiatan pembelajaran, maka kita tidak bisa lepas dari pengkajian tentang fungsi, tujuan dan kegunaan LKS itu sendiri. Dapat kita ketahui bahwa LKS memiliki setidaknya beberapa fungsi. Menurut Andi Prastowo (2014:205); Wijayanti (Ernawati 2017:5) fungsi LKS yaitu LKS dapat membantu guru dalam proses pembelajaran karena dapat meminimalkan peran guru dalam menjelaskan materi yang diajarkan.

Selain fungsi, adapula tujuan dalam penyusunan LKS. Menurut Prastowo (2012:206); Arsyad (Afifah 2014:3) tujuan dari penyusunan LKS yaitu LKS dapat mempermudah peserta didik untuk memahami materi yang disampaikan, melatih kemandirian peserta didik serta dapat memberikan pengalaman kepada peserta didik tentang peserta yang ada di lingkungan mereka.

Dalam pembuatan Lembar Kegiatan Siswa atau disebut dengan LKS setidaknya harus memuat beberapa struktur. Menurut Andi Prastowo (2012:207); Ernawati (2017:5) struktur LKS meliputi judul, petunjuk umum, materi pokok, tugas serta penilaian.

\section{METODE PENELITIAN}

Jenis penelitian yang digunakan dalam penelitian ini yaitu penelitian kualitatif deskriptif dengan pendekatan studi kasus.

Teknik pengumpulan data yang dilakukan pada penelitian ini akan dilakukan yaitu dengan studi dokumentasi serta observasi pada situs yang akan diteliti yaitu pasar dan wawancara kepada pengelola, pedagang dan pembeli serta juga penelitian ini akan mengumpulkan data dari sumber-sumber dokumen berupa kurikulum.

Teknik analisis data dari hasil yang didapatkan saat di pasar menggunakan teknik dari Miles dan Huberman dimana tekniknya mempunyai empat langkah, yaitu pengumpulan data (data collection), reduksi data (data reduction), penyajian data (data display) serta 
penarikan kesimpulan dan verifikasi data (data conclusion and verifying).

\section{HASIL DAN PEMBAHASAN}

Pertama, pengumpulan data. Pengumpulan data penelitian dengan menggunakan observasi, wawancara dan studi dokumentasi. Observasi dan wawancara dilakukan di pasar tradisional Cilimus dengan subjeknya yaitu pedagang, pembeli, dan distributor. Dengan instrumen menggunakan kamera dan perekam suara untuk mengambil data wawancara. Sedangkan studi dokumentasi dilakukan untuk mengumpulkan data untuk menghasilkan bahan ajar LKS.

Kedua, reduksi data. Kegiatan reduksi data dilakukan terus menerus selagi masih melakukan pengumpulan karena reduksi data adalah meringkas data yang telah didapatkan hasil wawancara dan observasi. Produk yang dihasilkan dari reduksi data adalah ringkasan hasil pengumpulan data.

Ketiga, penyajian data. Langkah selanjutnya adalah menyajikan data yang telah di reduksi ke dalam bentuk narasi, bagan dan sebagainya yang bisa menghasilkan kesimpulan selanjutnya.

Keempat, kesimpulan data. Kegiatan ini adalah langkah terakhir setelah ketiga langkah sudah dilakukan dan hasilnya berupa kesimpulan atas penelitian di pasar tradisional Cilimus berbentuk narasi tentang menjelaskan secara detail hasil penelitian. Kesimpulan tersebut juga harus diverifikasi, kegiatan ini pemikiran singkat peneliti untuk meninjau kembali hasil catatan penelitian di lapangan.

Penelitian ini dilakukan secara langsung di pasar tradisional Cilimus. Penelitian ini merujuk kepada mata pelajaran ekonomi dengan materi bab keseimbangan dan struktur pasar. Metode yang digunakan pada penelitian ini menggunakan metode penelitian kualitatif dengan pendekatan studi kasus. Teknik pengumpulan data yang digunakan yaitu dengan melakukan observasi, studi dokumentasi dan wawancara kepada pedagang dan pembeli di pasar tradisional
Cilimus. Data yang sudah terkumpul dapat diuraikan sebagai berikut.

\section{Kegiatan Ekonomi Di Pasar Tradisional Cilimus Yang Dapat Dimanfaatkan Sebagai Sumber Belajar Pada Mata Pelajaran Ekonomi SMA Kelas X}

Berdasarkan penelitian yang telah dilakukan tentang kegiatan ekonomi di pasar tradisional Cilimus, maka ditemukan beberapa kegiatan ekonomi yang dapat dimanfaatkan dan dapat dijadikan bahan ajar pembelajaran ekonomi tentang mata pelajaran ekonomi tingkat SMA kelas X semester 1 .

Pertama, kegiatan distribusi barang dagangan. Berdasarkan kegiatan ekonomi di pasar tradisional Cilimus terdapat tiga macam cara untuk memperoleh barang dagangan yaitu dengan cara pengiriman oleh distributor serta dengan cara memperoduksi sendiri.

Kedua, penyimpanan barang dagangan. Berdasarkan kegiatan ekonomi di pasar tradisional Cilimus terdapat tiga macam penyimpanan barang dagangan yang dilakukan oleh pedagang yaitu dengan cara disimpan di gudang, disimpan di lemari dalam kios serta dibawa pualng kembali ke rumah.

Ketiga, penyajian barang dagangan. Berdasarkan kegiatan ekonomi yang ada di pasar tradisional Cilimus ada beberapa cara pedagang untuk menyajikan barang dagangannya yang sesuai dengan barang dagangan yang di jualnya. Seperti daging-dagingan yang menggunakan meja los-losan yang panjang, untuk barang dagangan sembako seperti beras yang menggunakan kotak-kotak terbuka, adapula barang logam seperti cincin, kalung dan gelang yang menggunakan etalase kaca transparan.

Keempat, transaksi jual beli. Berdasarkan kegiatan ekonomi di pasar tradisional Cilimus, proses transaksi jual beli ada beberapa macam yaitu transaksi antara pedagang dengan distributor serta transaksi antara pedagang dan pembeli.

2. Desain Bahan Ajar LKS Berbasis Lingkungan Hasil Studi Kasus Di Pasar Tradisional Cilimus

a. Judul/Cover

Judul yaitu dimana judul ini ditentukan dari kompetensi-kompetensi dasar yang akan dicapai dalam pembelajaran atau pengalaman belajar yang terdapat dalam kurikulum,

b. Kompetensi Inti

Kompetensi inti adalah tingkat kemampuan untuk mencapai standar 
kompetensi lulusan yang harus dimiliki oleh peserta didik pada setiap tingkat, kelas ataupun program.

c. Kompetensi Dasar

Kompetensi dasar adalah kemampuan utuk mencapai kompetensi inti yang harus diperoleh oleh peserta didik melalui pembelajaran.

\section{d. Peta Konsep}

Peta konsep merupakan gambaran bagan yang menunjukan materi apa saja yang akan dicapai oleh peserta didik.

\section{e. Materi Pokok}

Materi pokok dalam LKS ini adalah hasil ringkasan dari penelitian yang sudah dilakukan di pasar tradisional Cilimus yang kemudian disesuaikan dengan kebutuhan kompetensi dasar yang ada.

\section{f. Tugas dan Langkah Kerja}

Tugas di dalam bahan ajar LKS yang telah dibuat disesuaikan dengan tujuan pembelajaran yang akan dicapai atau tujuan kompetensi dasar.

\section{Menurut Sanjaya (2014:255)} pembelajaran kontekstual adalah suatu strategi pembelajaran yanng menekankan kepada proses keterlibatan siswa untuk menemukan materi, artinya proses pembelajran lebih menekankan pada proses pengalaman langsung. Lebih lengkap lagi Majid (2014:228) menyatakan pembelajaran kontekstual merupakan suatu proses pembelajaran yang holistik dan bertujuan untuk memotivasi siswa memahami suatu makna materi pembelajaran dengan mengaitkan materi tersebut dengan kehidupan siswa sehari-hari. Pembelajaran kontekstual merupakan konsep belajar yang membantu guru mengaitkan materi pembelajaran dengan dunia nyata siswa dan mendorong siswa untuk membuat hubungan antara konsep yang dimilikinya dengan penerapannya dalam kehidupan sehari-hari sebagai bagian dari anggota keluarga maupun masyarakat (Shoimin. 2014: 41).

\section{KESIMPULAN DAN SARAN Kesimpulan}

Berdasarkan hasil penelitian mengenai pemanfaatan pasar sebagai sumber belajar pada mata pelajaran ekonomi kelas $\mathrm{X}$ maka dapat disimpulkan bahwasanya :

1. Kegiatan ekonomi di pasar tradisional Cilimus yang dapat dimanfaatkan sebagai sumber belajar pada mata pelajaran Ekonomi materi pada bab Keseimbangan dan Struktur Pasar yaitu: 1) Kegiatan distribusi barang dagangan, 2) Penyimpanan barang dagangan, 3) Penyajian barang dagangan, dan 4) Transaksi jual beli.

2. Desain bahan ajar LKS berbasis lingkungan hasil studi kasus di pasar tradisional Cilimus yaitu: 1) Judul/Cover, 2) Kompetensi Inti yang merujuk pada kurikulum 2013, 3) Kompetensi Dasar yaitu kemampuan untuk mencapai Kompetensi Inti, 4) Peta Konsep, 5) Materi Pokok, dan 6) Tugas dan Langkah Kerja. Desain bahan ajar LKS ini layak untuk dikembangkan dengan beberapa saran setelah melakukan validasi kepada ahli materi dan ahli media.

\section{Saran}

Berdasarkan kesimpulan yang dibuat peneliti dari hasil penelitian maka peneliti dapat memberikan saran sebagai berikut :

1. Bagi Guru

Sebagai seorang pendidik, guru diharapkan untuk menggunakan sumber belajar lain selain dengan menggunakan buku paket untuk proses pembelajaran yang efektif dengan memanfaatkan sumber belajar yang ada di lingkungan sekitarnya.

2. Bagi pihak Sekolah

Pihak sekolah merupakan pihak yang bertanggung jawab penuh terhadap keberhasilan belajar siswa dan diharapkan dapat mendukung untuk menerapkan sumber belajar lain secara optimal.

3. Bagi peneliti lain

Untuk peneliti lain disarankan dapat menindak lanjuti penelitian ini dalam hal memanfaatkan sumber belajar pasar ataupun sumber belajar lain yang dapat membantu dalam pembelajaran Ekonomi.

\section{DAFTAR RUJUKAN}

Abdullah, Ramli (2012). Pembelajaran Berbasis Pemanfaatan Sumber Belajar. Jurnal Ilmiah Didaktika, IAIN Ar-Raniry

AECT (Association for Educational Communication and Technology). Evaluating Media Programs District and School, Washington D.C : The Association, 2004 
Afifah, Rohmatun Nurul (2014). Pengembangan Lembar Kerja Siswa (LKS) Ilmu Pengetahuan Alam Berbasis Metode Percobaan. Jurnal Pendidikan, Universitas PGRI Yogyakarta

Bektaş, Mustafa. (2013). An Examination of the Elementary School Teachers' Preferred Teaching Methods and Instructional Technologies in Terms of Various Variables in Life Study Lesson. International Online Journal of Educational Sciences.

Belawati, Tian, dkk. (2003). Pengembangan Bahan Ajar. Jakarta: Pusat Penerbitan Universitas Terbuka

Brata, Ida Bagus (2015). Pasar Tradisional di Tengah Arus Budaya Global. Jurnal Ilmiah Didaktika, Universitas Mahasaraswati Denpasar

Diknas.2004. Pedoman Umum Pemilihan dan Pemanfaatan Bahan Ajar. Jakarta: DitjenDikdasmenum

Ernawati, Andi dkk (2017). Pengembangan Lembar Kerja Siswa Berbasis Multiple Intelligences pada Pokok Bahasan Substansi Genetika Kelas XII IPA SMA Negeri 16 Makassar. Jurnal Biotek, UIN Alauddin Makassar

Hamdani.(2011). Strategi Belajar Mengajar. Bandung: CV PustakaSetia.

Hidayat, Alvin (2014). Pemanfaatan Pasar Sebagai Sumber Belajar IPS Siswa Kelas VIII SMPN 66 Jakarta. Skripsi Pendidikan IPS, Universitas Islam Negeri Syarief Hidayatullah.

Lestari, Emy (2017). Efektivitas Pasar sebagai Sumber Belajar untuk Meningkatkan Kecerdasan Ruang Peserta Didik : Quasi Eksperimen di SMP Negeri 1 Tawangsari Kab. Sukoharjo Prop. Jawa Tengah. S2 thesis, Universitas Pendidikan Indonesia.

Lukman (2007). Pengantar Mikro Ekonomi. Jakarta:Lembaga Penelitian UIN Jakarta \& UIN Press.

Majid, Abdul. (2011). Perencanaan Pembelajaran : Mengembangkan Standar Kompetensi Guru. Bandung: Remaja Rosdakarya

Merida, Peggy Delita. (2016). Optimalisasi Sumber Belajar Ekonomi dalam
Pembelajaran Ekonomi di SMA. Jurnal Pendidikan. Universitas Negeri Malang

Pemerintah Indonesia. 2007. Undang-Undang Nomor 112 Tahun 2007 tentang Penataan dan Pembinaan Pasar Tradisional, Pusat Perbelanjaan dan Toko Modern. Lembaran Negara RI Tahun 2008, No 112. Sekretariat Negara. Jakarta.

Prastowo, Andi. (2011). Panduan Kreatif membuat Bahan Ajar Inovativ. Jogjakarta:Diva Press

Rahmatullah, R., Inanna, I., Rakib, M., Mustari, M., \& Rabania. (2020). Developing Tematic Economic Comic with Characters for Early Childhood. EST Journal of Educational Science and Technology, 6(3), 293-300

Rahmatullah, R., Inanna, I., \& Ampa, A. T. (2020). Media Pembelajaran Audio Visual Berbasis Aplikasi Canva. Jurnal Pendidikan Ekonomi Undiksha, 12(2), 317-327.

Ramli, A., Rahmatullah, Inanna, \& Dangnga, T. (2018). Peran Media Dalam Meningkatkan Efektivitas Belajar. Lembaga Pengabdian Kepada Masyarakat Universitas Negeri Makassar, 5-7. https://ojs.unm.ac.id/semnaslpm/article/dow nload/7649/4429\%0A

Sanjaya, Wina. 2014. Stategi Pembelajaran: Berorientasi Standar Proses Pendidikan. Jakarta: Kencana Prenada Media Group

Sari, Lila Fitria.(2013). Pengaruh Orientasi Pasar dan Kreativitas terhadap Kinerja Pemasaran Pedagang Pakaian Jadi di Pasar Kliwon Kabupaten Kudus. Management Analisys Journal, UniversitasNegeri Semarang.

Shoimin, Aris. 2014. 68 Model Pembelajaran Inovatif dalam Kurikulum 2013. Jogjakarta: Ar-Ruzz Media

Yulianti, Y. (2019). Contextual Teaching Learning Dalam Pembelajaran Ekonomi. Pinisi Business Administration Review, 1(2). 